CT\&F - Ciencia, Tecnología y Futuro - Vol. 4 Num. 5 Jun. 2012

ISSN 0122-5383

\title{
LAMINAR FLAME SPEED OF SOY AND CANOLA BIOFUELS
}

\author{
Juan-Sebastián Gómez-Meyer ${ }^{*}$, Subramanyam R. Gollahalli², Ramkumar N. Parthasarathy² \\ and Jabid-Eduardo Quiroga ${ }^{1}$
}

\author{
1 Universidad Industrial de Santander, Bucaramanga, Santander, Colombia \\ 2 School of Aerospace and Mechanical Engineering, University of Oklahoma, Norman, Oklahoma, U.S.A. \\ e-mail: i_gomez_meyer@hotmail.com gollahal@ou.edurrparthasarathy@ou.edu jabib@uis.edu.co
}

(Received Sep. 26, 2011 ; Accepted May 02, 2012)

\begin{abstract}
$\mathrm{n}$ this article, the flame speed values determined experimentally for laminar premixed flames of the vapors of two biofuels in air are presented. The laminar flame speed is a fundamental thermochemical property of fuels, and is essential for analyzing the flame propagation in practical devices, even those employing turbulent flames. The fuels obtained from transesterification of soy and canola oils are tested. Also, the diesel flames are studied to serve as a baseline for comparison. The experiments are performed with a tubular burner; pre-vaporized fuel is mixed with hot air and is ignited. The flame speed is determined at fuel-equivalence ratios of $1 ; 1,1$ and 1,2 by recording the geometry of the flame. The experimental results show that the flame speed of biofuels is lower by about $15 \%$ than that of diesel. Also, the maximum value of flame speed is obtained at an equivalence ratio of approximately 1,1 .
\end{abstract}

Keywords: Combustion, Biodiesel, Equivalence ratio, Laminar flame speed, Soy, Canola, Biofuels, Vegetable oil, Transesterification.

Citation: Gómez-Meyer, J. S. , Gollahalli, S. R. , Parthasarathy, R. N. \& Quiroga, J. E. (2012). Laminar flame speed of soy and canola biofuels. CT\&F - Ciencia, Tecnología y Futuro, 4 (5), 75-84.

*To whom correspondence should be addressed 


\section{RESUMEN}

$\mathrm{E}$

n este artículo, se presentan los valores de la velocidad de llama determinada experimentalmente para llamas premezcladas de vapores de dos biocombustibles. La velocidad de llama laminar es una propiedad termodinámica fundamental de los combustibles, y es esencial para analizar la propagación de la llama en dispositivos prácticos, incluso en los que trabajan con llamas turbulentas. Los combustibles obtenidos mediante el proceso de transesterificación de soya y canola son probados. También, las llamas producidas por combustible diesel son estudiadas para servir de base de comparación. Los experimentos son desarrollados en un quemador tubular, donde combustible pre-vaporizado mezclado con aire caliente es encendido. La velocidad de llama es determinada mediante un análisis geométrico a factores de aire (relación aire combustible) de 1; 1, 1 y 1,2. Los resultados experimentales muestran que las velocidades de llama de los biocombustibles son alrededor de 15\% más bajas de las del diesel. También que el máximo valor de velocidad de llama es encontrado cuando el factor de aire es de 1,1.

Palabras clave: Combustión, Biodiesel, Factor de aire, Velocidad de llama laminar, Soya, Canola, Biocombustibles, Aceites vegetales, Transesterificación.

\section{RESUMO}

N

Teste artigo, apresenta-se os valores da velocidade de chama determinada experimentalmente para chamas pré-misturadas de vapores de 2 biocombustíveis. A velocidade de chama laminar é uma propriedade termodinâmica fundamental dos combustíveis, e é essencial para analisar a propagação da chama em dispositivos práticos, incluso nos que trabalham com chamas turbulentas. Os combustíveis obtidos mediante o processo de transesterificação de soja e canola são provados. Também, as chamas produzidas por combustível diesel são estudadas para servir de base de comparação. Os experimentos são desenvolvidos em um queimador tubular, onde combustível pré-vaporizado misturado com ar quente é aceso. A velocidade de chama é determinada mediante uma análise geométrica a fatores de ar (relação ar combustível) de 1;1,1 e 1,2. Os resultados experimentais mostram que as velocidades de chama dos biocombustíveis são ao redor de 15\% mais baixas que as de diesel. Também que o máximo valor de velocidade de chama é encontrado quando o fator de ar é de 1,1.

Palavras chave: Combustão, Biodiesel, Fator de ar, Velocidade de chama laminar, Soja, Canola, Biocombustíveis, Óleos vegetais, Transesterificação. 


\section{INTRODUCTION}

Biofuels are derived from biomass, such as vegetable matter and animal fats. Biofuels include solid biomass, liquid fuels and various biogases. The current biofuels include bioalcohols, biodiesels, and biogases. Biodiesel is produced from oils or fats using transesterification and is a liquid with composition and properties somewhat similar to those of fossil/ mineral diesel; a major distinction is that biodiesel has oxygen in its molecular content and does not contain aromatics and cycloalkanes. Biodiesel can be used as a fuel in diesel engines in its pure form, but it is usually used as a diesel additive in different proportions to reduce emission levels of particulates, carbon monoxide, and hydrocarbons from dieselpowered vehicles.

Biofuels are gaining increased public and scientific attention, driven by factors such as oil price spikes, the need for increased energy security and concern over greenhouse gas emissions from fossil fuels. The compatibility of biofuels with petroleum fuels makes them an attractive candidate as an alternate fuel for use in transportation. There have been a number of studies on the performance of biofuels in engines. Schumacher et al. (2001) compared the performance of two diesel engines that were fueled with various blends of biofuel and petroleum diesel fuel. The results of this study were in agreement with those from previous studies on two and four stroke diesel engines; an increase in $N O_{x}$ emissions, accompanied by a decrease in $C O$, Particulate Matter (PM) and unburned hydrocarbons was observed. Canakci and Gerpen (2003) used petroleum diesel, yellow grease biofuel and soybean oil biofuel in a four-cylinder turbocharged diesel engine, at steady state engine operating conditions. The use of both biofuels resulted in significant reductions in $P M$, $\mathrm{CO}$, and unburned hydrocarbons. Another study by Labeckas and Slavinskas (2006) showed the effects of Rapeseed Methyl Ester (RME) on the exhaust emissions in a four-stroke, four-cylinder diesel engine. The engine was operated on neat RME and its 5; 10; 20 and $35 \%$ blends with diesel fuel. An increase in $N O_{x}$ emissions was observed with increasing engine speed; the result was attributed to the increased mass percentage of oxygen in the biofuel.
In an effort to understand the combustion characteristics of biofuels in a more fundamental manner, Love, Parthasarathy and Gollahalli (2009a) developed a method of rapidly measuring the flame properties of liquid fuels in a controlled laminar flame environment, thus eliminating some of the physical variables such as spray atomization, evaporation and turbulence that occur in an engine. The variation of pollutant emissions with fuel in this study agreed with those measured in engines.

Using the same experimental set-up Love, Parthasarathy and Gollahalli (2009b) found that the fuel iodine number had a significant effect on the formation of $N O_{x}$. In a companion study Love, Parthasarathy and Gollahalli (2011) observed that the mechanisms of $N O_{x}$ formation in these laminar flames changed with the injector exit equivalence ratio.

While the nature of pollutant emission with the use of biofuels has been documented, there have been limited studies of laminar flame studies of biofuels. The laminar flame speed is a fundamental thermochemical property of fuels, and is essential for analyzing flame propagation, lift-off, and blowout. The laminar flame speed is dependent on the chemical composition of the fuel in addition to the pressure, temperature, and the air/fuel mixture ratio. Biofuels are produced from a variety of sources, such as vegetable oils and cellulose; therefore, documentation of the laminar flame speed of these fuels is important for developing models of biofuel combustion. Chong and Hochgreb (2011) measured the laminar flame speeds of blends of Palm Methyl Ester (PME) and diesel and PME and Jet A. A jet-wall stagnation flame configuration was used and velocity measurements were made using Particle Image Velocimetry (PIV) at atmospheric pressure and a temperature of $470 \mathrm{~K}$. The flame velocity measurements were made at various strain rates and extrapolated to determine the laminar flame speed at zero strain rate. The laminar flame speed of PME was similar to that of diesel, but peaked at a slightly richer fuel/air mass ratio. The equality of the laminar flame speeds of the two fuels was attributed to the almost equal adiabatic flame temperatures of the two fuels. The presence of $C-O$ bonds in the fuel was responsible for the shift of the maximum laminar flame speed to richer equivalence ratios. Wang, Feng, Egolfoupolos and Tsotsis (2011) measured the laminar flame 
speed of three model biodiesel fuels (methyl butanoate, methyl crotonoate and methyl decanoate) in a laminar counterflow burner at atmospheric pressure and a temperature of $403 \mathrm{~K}$. The velocities at various stretch rates were measured using PIV and the laminar flame speed was obtained by extrapolating the measurements to zero stretch rate. It was found that the presence of the ester group had a retarding effect on the mixture reactivity, resulting in lower laminar flame speeds for the methyl butanoate/air flames compared to n-butane/air flames.

The objective of this study is to document the laminar flame speeds of two biofuels: Soy Methyl Ester (SME) and Canola Methyl Ester (CME) and compare the measurements with those of diesel. The measurements are made at atmospheric pressure, similar to previous studies. The laminar flame speed is obtained from the flame geometry documented in a Bunsen burner. The method is simple and eliminates the problems associated with the introduction of seed particles in the flow (for velocity measurements using PIV) and the uncertainties associated with the extrapolation of the measurements to zero stretch rates. For relative evaluation of the laminar flames speeds of different fuels, this method is satisfactory. The experimental set-up and procedures are described next.

\section{EXPERIMENTAL SET-UP AND PROCEDURE}

The simple, reliable, and well-established Bunsen flame method is used in this study to measure the flame speed. The set-up is similar to that used by Love et al. (2009a) in their laminar flame studies. The fuel/air mixture is passed through a vertical circular tube $(9,5$ $\mathrm{mm}$ inner diameter and $178 \mathrm{~mm}$ long) and burned after exiting the tube. The liquid fuel is injected at a constant volume flow rate into a hot air stream using a syringe pump, Figure 1a. The air stream is pre-heated using heating tapes wrapped around the tube carrying the air flow, Figure $1 \mathrm{~b}$. The air is heated to $350^{\circ} \mathrm{C} \pm 1^{\circ} \mathrm{C}$, which is sufficiently high to vaporize the liquid fuel, without any coking. The liquid fuel is injected into the coflow air as small drops, which prevents the drops from hitting the hot wall before vaporization. This was verified by opening up the tubes and checking for any wall deposits after hours of operation. Moreover, the heated line is maintained at a temperature such that the partial pressure of the fuel is below the saturation pressure; this prevents any condensation of the fuel. The volume flow rate of air is monitored using a rotameter.

The test bench used for the experimentation is shown in Figure 1c. The equivalence ratio is changed by altering the air flow rate, while keeping the fuel flow rate constant. The fuel/air mixture is ignited using a pilot flame, which is removed after ignition. The resulting flame is laminar, with properties dependent primarily on the fuel chemistry. Multiple pictures of the flame

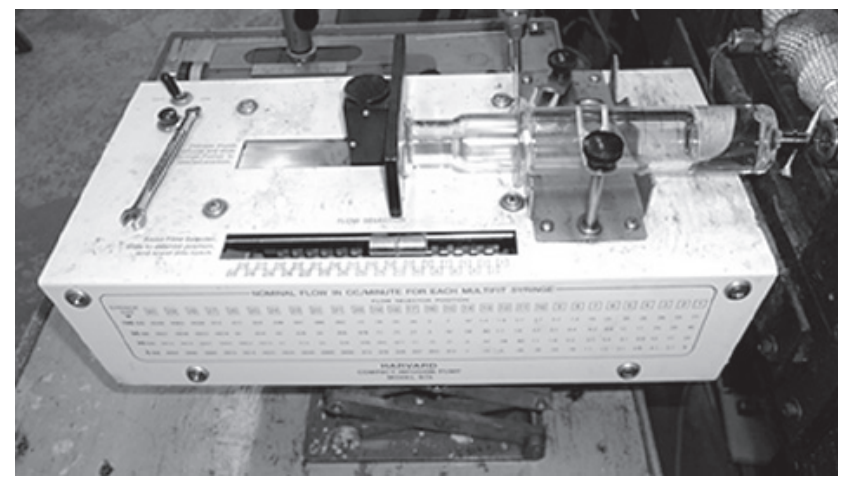

(a)

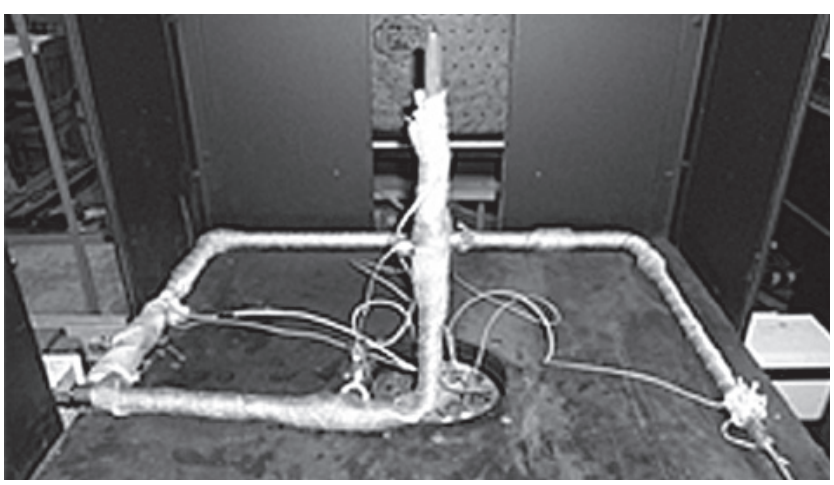

(b)

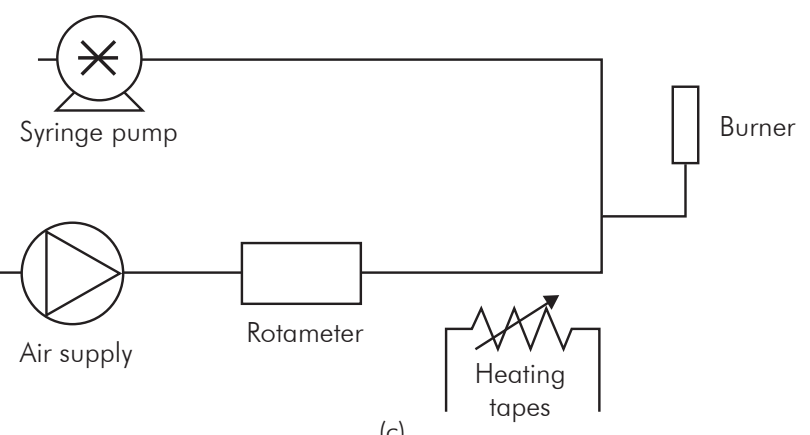

(c)

Figure 1. (a) Syringe pump. (b) Burner set-up. (c) Schematic representation of the experimental set-up. 
are taken using a still-picture camera with exposure settings between $1 / 30$ and $1 / 40 \mathrm{~s}$.

A laminar conical flame, such as that illustrated in Figure 2, is obtained. The major difficulty in flamespeed studies is that the flame front (reaction zone) can be rarely seen as planar, stationary and adiabatic, which is very important in the accuracy of the measurements. Usually, the upstream flow is non-uniform while the

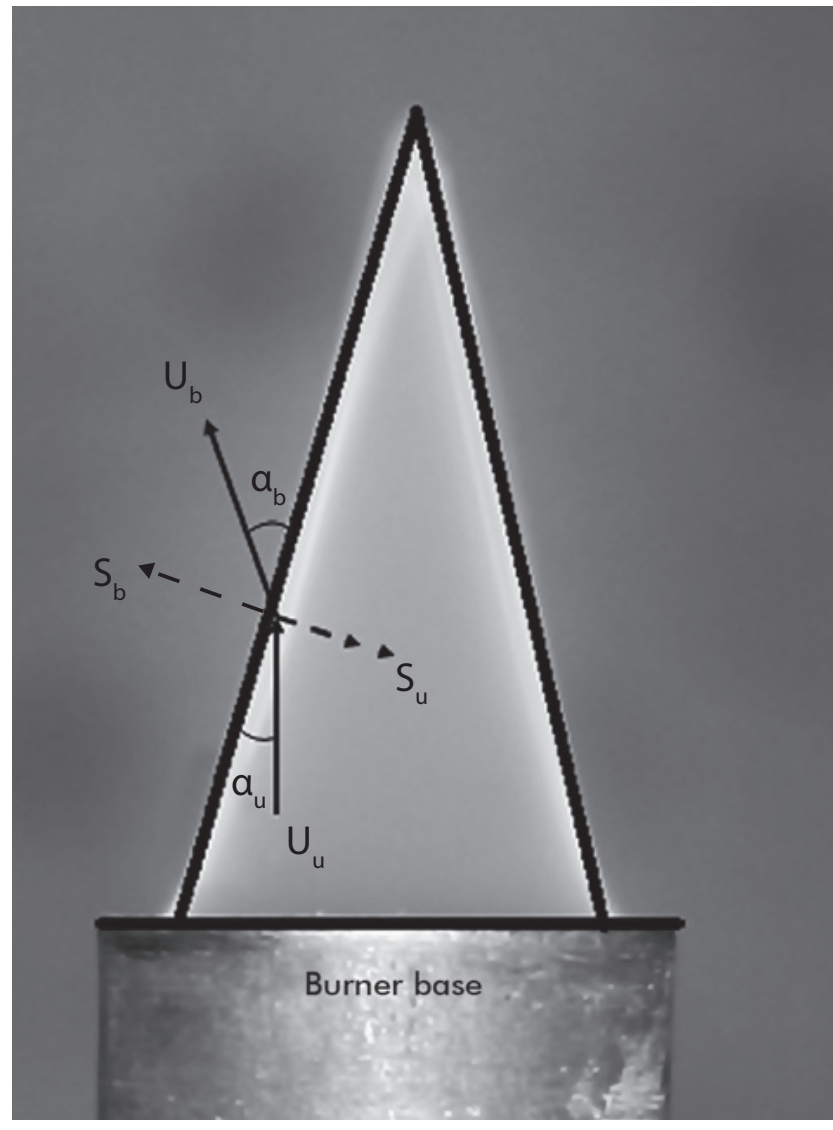

Figure 2. Definitions of the upstream and downstream laminar flame speeds. flame is also either propagating and/or curved. In Figure 2, that the upstream unburned mixture approaches the flame front with velocity $u_{u}$ and at an angle $\alpha_{u}$. After passing through the flame, the flow is deflected and the burned mixture leaves the flame with velocity $u_{b}$ and at an angle $\alpha_{b}$. In this case, the laminar flame speed can be defined as the normal component of $u_{u}$, pointed in the direction away from the flame.

Several pictures are taken for each condition; the flame geometry is measured for each picture, and an average value for the flame height and the cone angle (based on at least eight measurements) is used to compute the flame velocity using Equation 1.

$S_{u}=\frac{\dot{m}}{\rho_{u} * A_{f}}$

Here $S_{u}$ is the flame speed, is the mass flow of the air-fuel mixture, $A_{f}$ is the area of the outer cone (computed from the flame images) and $\rho_{u}$ is the density of the air-fuel mix. The density of the air-fuel mixture is calculated using the individual densities and mole fractions and the temperature. The accuracy of this laminar-flame velocity measurement method was verified by measuring the flame speed of propane at room temperature and atmospheric pressure and comparing it with the values published in the literature (Turns, 2000).

The fuels studied are Num. 2 diesel, SME, CME. The properties of the fuels are presented in Table 1 . It is observed that the biofuels have oxygen present in the fuel molecule and have a slightly lower heating value than Num. 2 diesel. The biofuels have a lower heating value (by about 10\%) and a higher viscosity than diesel.

Table 1. Properties of Fuels Tested.

\begin{tabular}{|c|c|c|c|c|c|}
\hline Fuel & Molecular Formula & $\begin{array}{c}\text { Density } \\
\left(\mathrm{kg} / \mathrm{m}^{3}\right)\end{array}$ & $\begin{array}{c}\text { Boiling Point } \\
\left({ }^{\circ} \mathrm{C}\right)\end{array}$ & $\begin{array}{c}\text { Viscosity } \\
(\mathrm{cSt})\end{array}$ & $\begin{array}{c}\text { Heating Value } \\
(\mathrm{MJ} / \mathrm{kg})\end{array}$ \\
\hline Num. 2 Diesel Fuel & $\mathrm{C}_{16} \mathrm{H}_{34}$ & 850 & $150-350$ & 4,61 at $25^{\circ} \mathrm{C}$ & 42,6 \\
\hline $\mathrm{CME}$ & $\mathrm{C}_{19} \mathrm{H}_{36} \mathrm{O}_{2}$ & 876 & $340-405$ & 4,37 at $40^{\circ} \mathrm{C}$ & 39,8 \\
\hline SME & $\mathrm{C}_{18,8} \mathrm{H}_{34,6} \mathrm{O}_{2}$ & 879 & $351-405$ & 4,34 at $40^{\circ} \mathrm{C}$ & 39,7 \\
\hline
\end{tabular}




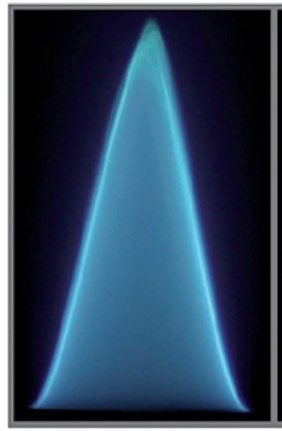

$\phi=1,04$

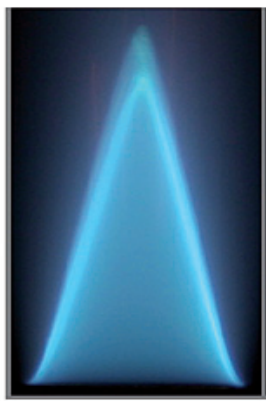

$\Phi=1,0$

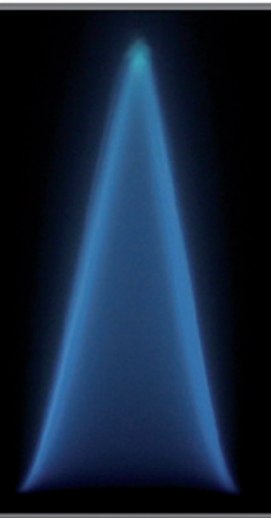

$\Phi=1,0$

Figure 3. Photographs of laminar flames of various fuels. (a) Diesel, (b) $C M E$, (c) SME.

\section{RESULTS}

Typical pictures of the flames of the different fuels are presented in Figure 3 at different equivalence ratios $(\phi)$. The flames appear blue due to the predominance of the homogeneous gas-phase reactions at these conditions. The flames are laminar with a well-defined conical shape.

\section{DISCUSSION}

The measured laminar flame velocities are presented in Table 2 and Figure 4. The laminar flame velocity of diesel of $128 \mathrm{~cm} / \mathrm{s}$ at an equivalence ratio of 1,1 is high because of the initial high temperature $\left(350^{\circ} \mathrm{C}\right)$ of the fuel-air mixture. Zhao et al. (2004) measured a laminar flame velocity of $95 \mathrm{~cm} / \mathrm{s}$ for n-decane at an initial temperature of $500 \mathrm{~K}$ and an equivalence ratio of 1,1. Chong and Hochgreb (2011) measured a laminar flame speed of diesel using PIV of $86,7 \mathrm{~cm} / \mathrm{s}$ at a temperature of $470 \mathrm{~K}$ and $1 \mathrm{~atm}$. Considering a temperature dependence of $\mathrm{T}^{1,5}$ for the laminar flame velocity, the predicted flame velocity of diesel at $623 \mathrm{~K}$ using these values is $132,2 \mathrm{~cm} / \mathrm{s}$, which is within $3 \%$ of the measured value. Moreover, the $\mathrm{n}$-decane flame velocity at an equivalence ratio of 1,1 ; predicted using the expression of Wagner and Dugger (1955) is $138 \mathrm{~cm} / \mathrm{s}$ at $623 \mathrm{~K}$, which is within $10 \%$ of the present measured value. Thus, the present diesel flame velocity measurements agree well with those provided in literature, lending confidence to the present measurement technique.

The flame velocities of CME and SME are lower than that of diesel, by about $12-15 \%$ at all equivalence ratios.

Table 2. Flame speeds of fuels tested at unburned gas temperature of $350^{\circ} \mathrm{C}$ and 1 atm pressure.

\begin{tabular}{|c|c|c|c|c|c|c|c|c|}
\hline \multicolumn{3}{|c|}{ DIESEL } & \multicolumn{3}{|c|}{ CME } & \multicolumn{3}{|c|}{ SME } \\
\hline$\phi$ & $\mathrm{S}_{\mathrm{u}}(\mathrm{cm} / \mathrm{s})$ & Uncertainty* (\%) & $\phi$ & $\mathrm{S}_{\mathrm{u}}(\mathrm{cm} / \mathrm{s})$ & Uncertainty* (\%) & $\phi$ & $\mathrm{S}_{\mathrm{u}}(\mathrm{cm} / \mathrm{s})$ & Uncertainty* (\%) \\
\hline 1,04 & 125,8 & 1,2 & 1 & 106,8 & 1,8 & 1 & 93,9 & 1,9 \\
\hline 1,1 & 128,5 & 1,3 & 1,1 & 110,5 & 1,7 & 1,1 & 107,5 & 1,5 \\
\hline 1,2 & 116,3 & 1,5 & 1,2 & 104,2 & 1,4 & 1,2 & 106,4 & 1,4 \\
\hline
\end{tabular}

Uncertainty* computed at $95 \%$ 


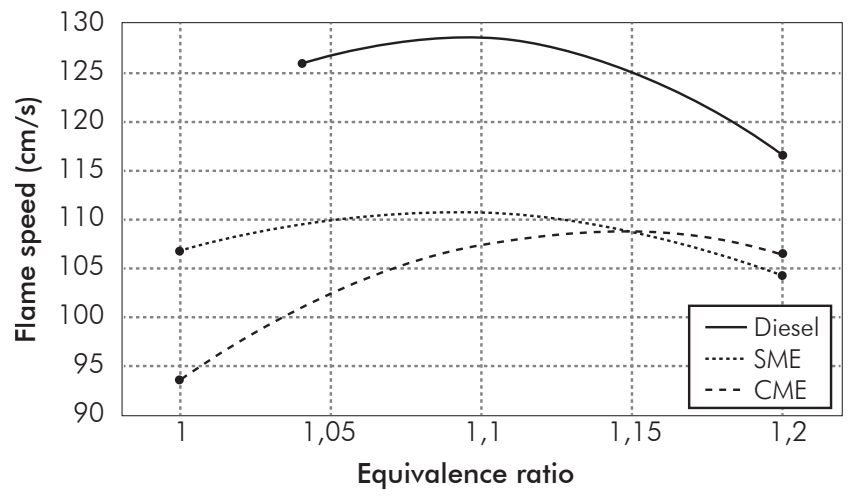

Figure 4. Change in laminar flame speed of CME, SME and diesel with equivalence ratio, at unburned gas temperature of $350^{\circ} \mathrm{C}$ and $1 \mathrm{~atm}$.

Both biofuels contain about the same mass percentage of oxygen (11\%). The adiabatic flame temperatures of CME and SME are $2268 \mathrm{~K}$ and $2266 \mathrm{~K}$, only slightly lower than that of diesel $(2282 \mathrm{~K})$. The lower laminar flame speed of the biofuels is then attributed to the retarding of the mixture reactivity by the methyl ester group, confirmed by the observations of Wang et al. (2011). It must be noted that the present results are different from those of Chong and Hochgreb (2011) who found no difference in the laminar flame speeds of PME and diesel. The dependence of the laminar flame speed on the chemical composition of the biofuel and feed stock used in preparing it, is evident in these results.

The peak flame velocity is not significantly different between the two biofuels, SME and CME. Although it seems surprising in view of the difference in iodine number between SME $(141,6)$ and CME $(110)$, it is understandable because the effect of unsaturation vanishes for large molecules containing more than eight carbon atoms (Kanury, 1975). SME contains more double bonds than CME, which results in different combustion characteristics, such as higher $N O_{x}$ emission than CME (Love et al., 2009b).

For all the fuels, the burning velocity reached a maximum around a stoichiometric ratio of 1,1 ; similar to observations by Zhao et al. (2004). Since biofuels are normally used as blends with diesel, it is really important that flame speed obtained for biofuels is comparable to that of diesel. Measurements of laminar flame speeds of biofuel blends are needed to understand this dependence further.

The measured flame heights are presented in Table 3 and Figure 5. The flame height is important to understand $N O_{x}$ production and residence-time calculations. Furthermore, the large differences in flame height could alter the levels of uncertainty in measurements of cone angle and consequently the measured values of flame velocity. The flame heights are comparable for all the fuels. The absence of large differences in flame height indicates that the errors introduced in measurement of laminar flame velocity due to the flame height are small, at least for relative comparisons.

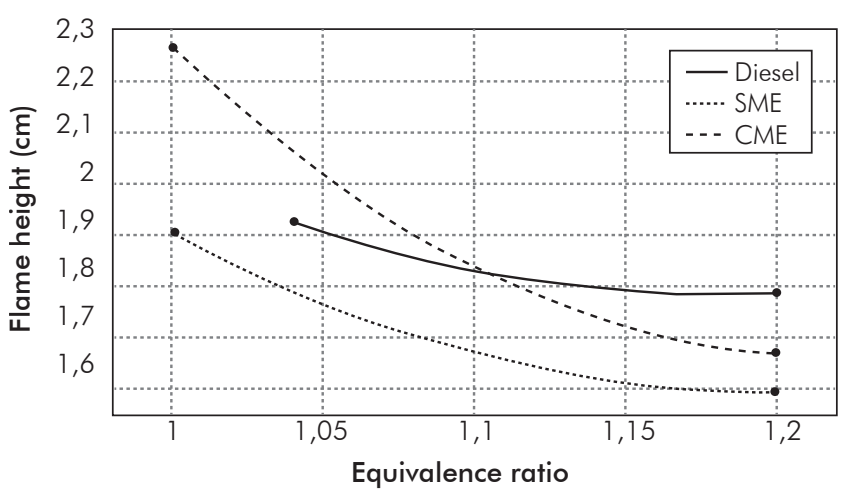

Figure 5. Variation of flame height with equivalence ratio, at unburned gas temperature of $350^{\circ} \mathrm{C}$ and $1 \mathrm{~atm}$ pressure.

Table 3. Measured Flame Heights of Different Fuels at unburned gas temperature of $350^{\circ} \mathrm{C}$ and 1 atm pressure.

\begin{tabular}{|c|c|c|c|c|c|c|c|c|}
\hline \multicolumn{3}{|c|}{ DIESEL } & \multicolumn{3}{c|}{ CME } & \multicolumn{3}{c|}{ SME } \\
\hline$\phi$ & $\mathrm{h} \mathrm{(cm)}$ & Uncertainty* (\%) & $\phi$ & $\mathrm{h}(\mathrm{cm})$ & Uncertainty* (\%) & $\phi$ & $\mathrm{h}(\mathrm{cm})$ & Uncertainty* (\%) \\
\hline 1,04 & 1,93 & 0,9 & 1 & 1,90 & 3,8 & 1 & 2,26 & 3,1 \\
\hline 1,1 & 1,83 & 1,8 & 1,1 & 1,67 & 3,0 & 1,1 & 1,84 & 1,2 \\
\hline 1,2 & 1,79 & 1,9 & 1,2 & 1,60 & 1,2 & 1,2 & 1,67 & 0,9 \\
\hline
\end{tabular}




\section{CONCLUSIONS}

- In this study, the laminar flame speeds of pure CME and SME are measured and compared with those for diesel and various fuel-rich equivalence ratios. The flame speeds of these biofuels are lower than that of diesel by about $12-15 \%$ at each equivalence ratio. The peak values of laminar flame speed of the tested biofuels are essentially the same. The laminar flame heights of all the three fuels are also of comparable magnitude. Thus, biofuels obtained from canola and soy oil have some diesel-like combustion properties, which make them attractive alternatives for petroleum diesel.

\section{REFERENCES}

Canakci, M. \& Gerpen, J. (2003). Comparison of engine performance and emissions for petroleum diesel fuel, yellow grease biofuel and soybean oil biofuel. Trans. of the American Soc. of Agricult. and Biolog. Eng., 46 (4), 937-944.

Chong, C. T. \& Hochgreb, S. (2011). Measurements of laminar flame speeds of liquid fuels: Jet-A1, diesel, palm methyl esters and blends using Particle Imaging Velocimetry (PIV). Proceedings of the Combustion Institute, 33 (1), 979-986.

Kanury, A. M. (1975). Introduction to Combustion Phenomena. Philadelphia: Gordon and Breach.

Labeckas, G. \& Slavinskas, S. (2006). The effect of rapeseed oil methyl ester on direct injection engine performance and exhaust emissions. Energy Conver and Manage., 47 (13-14), 1954-1967.

Love, N. D., Parthasarathy, R. N. \& Gollahalli, S. R. (2009a). Rapid characterization of radiation and pollutant emissions of biodiesel and hydrocarbon liquid diesel fuels. J. Energy Resour. Technol., 131 (1), 012202-1 - 012202-8.

Love, N. D., Parthasarathy, R. N. \& Gollahalli, S. R. (2009b). Effect of iodine number on $N O_{x}$ formation in laminar flames of oxygenated biofuels. Inter. J. of Green Energy, 6 (4), 323-332.

Love, N. D., Parthasarathy, R. N. \& Gollahalli, S. R. (2011). Concentration measurements of $\mathrm{CH}$ and $\mathrm{OH}$ radicals in laminar biofuel flames. Inter. J. of Green Energy, 8 (1), 113-120.

Schumacher, L., Marshall, W., Krahl, J., Wetherell, W. \& Grabowski, M. (2001). Biofuel emissions data from series 60 DDC engines. Transactions of the ASABE, 44 (6), 1465-1468.

Turns, S. R. (2000). An introduction to combustion: concepts and applications. New York: McGraw-Hill.

Wagner, P. \& Dugger, G. (1955). Flame propagation. V. Structural influence on burning velocity. Comparison of measured and calculated burning velocity. J. Am. Chem. Soc. , 77 (1), 227-231.

Wang, Y. L., Feng, Q., Egolfoupolos, F. N. \& Tsotsis, T. T. (2011). Studies of C4 and C10 methyl ester flames. Combustion and Flame, 158 (8), 1507-1519.

Zhao, Z., Li, J., Kazakov, A., Dryer, F. L. \& Zeppieri, S. P. (2004). Burning velocity and a high temperature skeletal kinetic model for n-decane. Combust. Sci. Tech. , 177 (1), 89-106. 


\begin{tabular}{|c|c|}
\hline & \multicolumn{1}{c|}{ NOTATION } \\
& \\
$U_{u}$ & Unburned air-fuel mixture velocity, $\mathrm{cm} / \mathrm{s}$ \\
$U_{b}$ & Burned air-fuel mixture velocity, $\mathrm{cm} / \mathrm{s}$ \\
$S_{u}$ & Laminar flame speed unburned side, $\mathrm{cm} / \mathrm{s}$ \\
$S_{b}$ & Laminar flame speed burned side, $\mathrm{cm} / \mathrm{s}$ \\
$\alpha_{u}$ & Unburned air-fuel mixture velocity angle \\
$\alpha_{b}$ & Burned air-fuel mixture velocity angle \\
$\dot{m}$ & Mass flow of the air-fuel mixture, $\mathrm{kg} / \mathrm{s}$ \\
$\rho_{u}$ & Density of the air-fuel mixture, $\mathrm{kg} / \mathrm{cm}^{3}$ \\
$A_{f}$ & Superficial area of the outer cone, $\mathrm{cm}^{2}$ \\
$\phi$ & Equivalence ratio, $\%$ \\
\hline
\end{tabular}


